\title{
Micronutrient Depletion in Heart Failure: Common, Clinically Relevant and Treatable
}

\author{
Natasa Cvetinovic ${ }^{1}$, Goran Loncar ${ }^{2,3}$, Andjelka M. Isakovic ${ }^{3}$, Stephan von Haehling ${ }^{4,5}$, \\ Wolfram Doehner ${ }^{6} \mathbb{D}$, Mitja Lainscak ${ }^{7,8, *}$ and Jerneja Farkas ${ }^{9,10, *}$ \\ 1 Department of Cardiology, University Clinical Hospital Center “Dr. Dragisa Misovic-Dedinje”, \\ 11000 Belgrade, Serbia; ncvetinovic@gmail.com \\ 2 Institute for Cardiovascular Diseases Dedinje, 11000 Belgrade, Serbia; loncar_goran@yahoo.com \\ 3 School of Medicine, University of Belgrade, 11000 Belgrade, Serbia; andjelka.isakovic@gmail.com \\ 4 Department of Cardiology and Pneumology, University of Goettingen Medical Center, \\ DE-37075 Goettingen, Germany; stephan.von.haehling@med.uni-goettingen.de \\ 5 German Center for Cardiovascular Research (DZHK), partner site Goettingen, \\ DE-37099 Goettingen, Germany \\ 6 Berlin Institute of Health Center for Regenerative Therapies (BCRT) and Department of Cardiology \\ (Virchow Klinikum), German Centre for Cardiovascular Research (DZHK) partner site Berlin, \\ Charité Universitätsmedizin Berlin, DE-13353 Berlin, Germany; wolfram.doehner@charite.de \\ 7 Division of Cardiology, General Hospital Murska Sobota, SI-9000 Murska Sobota, Slovenia \\ 8 Faculty of Medicine, University of Ljubljana, SI-1000 Ljubljana, Slovenia \\ 9 Research Unit, General Hospital Murska Sobota, SI-9000 Murska Sobota, Slovenia \\ 10 National Institute of Public Health, SI-1000 Ljubljana, Slovenia \\ * Correspondence: mitja.lainscak@guest.arnes.si (M.L.); jerneja.farkas@sb-ms.si (J.F.)
}

Received: 14 October 2019; Accepted: 4 November 2019; Published: 11 November 2019

\begin{abstract}
Heart failure (HF) is a chronic condition with many imbalances, including nutritional issues. Next to sarcopenia and cachexia which are clinically evident, micronutrient deficiency is also present in HF. It is involved in HF pathophysiology and has prognostic implications. In general, most widely known micronutrients are depleted in HF, which is associated with symptoms and adverse outcomes. Nutritional intake is important but is not the only factor reducing the micronutrient availability for bodily processes, because absorption, distribution, and patient comorbidity may play a major role. In this context, interventional studies with parenteral micronutrient supplementation provide evidence that normalization of micronutrients is associated with improvement in physical performance and quality of life. Outcome studies are underway and should be reported in the following years.
\end{abstract}

Keywords: heart failure; micronutrients; iron; vitamins; trace elements

\section{Introduction}

Heart failure (HF) is a complex disease with many potential underlying causes, which affects the function of other tissues and is often followed by comorbidities [1], especially in the elderly [2]. Pathogenesis of HF has been elucidated and includes many mechanisms, such as increased hemodynamic overload, ischemic-related dysfunction, ventricular remodeling, excessive neurohormonal stimulation, abnormal cardiomyocyte calcium cycling, excessive or inadequate accumulation of extracellular matrix, accelerated apoptosis, and genetic mutations [1]. Although no single unifying pathogenetic theory can explain HF completely, there is evidence suggesting that declining bioenergy plays a major role [3]. Fatty acids and carbohydrates are the main energy source for cardiomyocytes. The conversion of these macronutrients to biological energy requires micronutrients such as coenzyme Q10, thiamine, 
riboflavin, etc., which are essential cofactors for energy production, energy transfer, and maintenance of the physiological heart function [4]. Moreover, patients with HF have oxidative stress, inappropriate food intake (Table 1), altered metabolism and intestinal function, and pro-inflammatory status, which leads to a deficiency of micronutrients (e.g., iron, selenium, and zinc) and consequently affects prognosis. This review aims to underline the role of micronutrients in the pathophysiology of HF, their prognostic implications, and the effects of supplementation. We reviewed micronutrients that were most represented in the literature and could potentially have the most beneficial effects when supplemented in HF patients, namely B complex vitamins (B1, B2, B6, B12), vitamin C, trace elements selenium, zinc, and iron, coenzyme Q10, with a special attention on vitamin D due to a long history of its research and supplementation, and the abundance of available data.

Table 1. Recommended micronutrient dietary allowance for the general population.

\begin{tabular}{ccc}
\hline Micronutrient & RDA & Reference \\
\hline Vitamin D & $15-20 \mu \mathrm{g} /$ day & {$[5,6]$} \\
\hline Thiamin (B1) & $1.1-1.2 \mathrm{mg} /$ day & {$[7]$} \\
\hline Riboflavin (B2) & $0.9-1.3 \mathrm{mg} /$ day & {$[8]$} \\
\hline Pyridoxine (B6) & $1.6-2.0 \mathrm{mg} /$ day & {$[9]$} \\
\hline Cobalamin (B12) & $2.0-2.4 \mu \mathrm{g} /$ day & {$[10]$} \\
\hline Vitamin C & $75-90 \mathrm{mg} /$ day & {$[11]$} \\
\hline Coenzyme Q10 & $\mathrm{n} . \mathrm{a}$. & \\
\hline Selenium & $55 \mu \mathrm{g} /$ day & {$[10]$} \\
\hline Zinc & $8-11 \mathrm{mg} /$ day & {$[11]$} \\
\hline Iron & $8-18 \mathrm{mg} /$ day & {$[11]$}
\end{tabular}

RDA: recommended dietary allowance. n.a.: not assessed. * no RDA has been established.

\section{Vitamin D}

Although many diseases (e.g., cancer, autoimmune disorders, infertility and pregnancy complications, insulin resistance, and type 2 diabetes mellitus) are associated with vitamin D levels, its metabolism, and vitamin D-related genes [12,13], the association between vitamin D and cardiovascular disease is still controversial. Vitamin D regulates numerous processes involved in the pathogenesis of $\mathrm{HF}$, such as cell proliferation and differentiation, apoptosis, oxidative stress, inflammation, endothelial function, vascular calcification, and activation of the renin-angiotensin system [14]. Observational studies have reported that subjects with lower vitamin D levels are under higher risk of developing HF $[15,16]$. Vitamin D deficiency (Table 2) is one of the most common types of hypovitaminosis worldwide, with a prevalence of almost $50 \%$ among the elderly [17], and is the most common vitamin deficiency in HF [18]. It is more common among patients with HF compared with healthy control individuals, independently of age [19]. While $90-99 \%$ of elderly HF patients are affected by vitamin D deficiency $[17,20,21]$, severe deficiency is reported in $17-68 \%$ of HF patients, dependent on age, gender, functional status, HF severity, and left ventricle ejection fraction (LVEF) $[17,20,22]$. Pathophysiology of vitamin D deficiency includes reduced food intake and intestinal absorption of nutrients, and limited exposure to solar ultraviolet light (Table 1). Accordingly, both aging and HF predispose patients to hypovitaminosis, and they may have an additive effect on vitamin D level in elderly patients. In light of the above, it is reasonable to evaluate vitamin D status in HF patients separately according to age. 
Table 2. Serum normal concentrations and definition of deficiency of micronutrients.

\begin{tabular}{|c|c|c|c|c|}
\hline Micronutrient & Reference Range & Insufficiency & Deficiency & Reference \\
\hline Vitamin D & $\begin{array}{l}>30 \mathrm{ng} / \mathrm{mL} \\
>75 \mathrm{nmol} / \mathrm{L}\end{array}$ & $\begin{array}{c}21-29 \mathrm{ng} / \mathrm{mL} \\
52.5-72.5 \mathrm{nmol} / \mathrm{L}\end{array}$ & $\begin{array}{l}<20 \mathrm{ng} / \mathrm{mL} \\
<50 \mathrm{nmol} / \mathrm{L}\end{array}$ & [23] \\
\hline Thiamin (B1) * & $\begin{array}{c}25-75 \mathrm{ng} / \mathrm{mL} \\
75-195 \mathrm{nmol} / \mathrm{L}\end{array}$ & & & [24] \\
\hline Riboflavin (B2) a & & & EGRAC $\geq 1.3$ & [25] \\
\hline Pyridoxine (B6) ${ }^{b}$ & $\begin{array}{c}5-50 \mathrm{ng} / \mathrm{mL} \\
23-223 \mathrm{nmol} / \mathrm{L}\end{array}$ & 20-30 nmol/L & $<20 \mathrm{nmol} / \mathrm{L}$ & [26-28] \\
\hline Cobalamin (B12) & $\begin{array}{l}180-950 \mathrm{pg} / \mathrm{mL} \\
125-701 \mathrm{pmol} / \mathrm{L}\end{array}$ & & $\begin{array}{l}<200 \mathrm{pg} / \mathrm{mL} \\
<148 \mathrm{pmol} / \mathrm{L}\end{array}$ & {$[29,30]$} \\
\hline Vitamin C & $>50 \mu \mathrm{mol} / \mathrm{L}$ & $10-50 \mu \mathrm{mol} / \mathrm{L}$ & $<10 \mu \mathrm{mol} / \mathrm{L}$ & [31] \\
\hline Coenzyme Q10 & $0.5-1.7 \mu \mathrm{mol} / \mathrm{L}$ & & & [32] \\
\hline Selenium & $\begin{array}{l}70-150 \mathrm{ng} / \mathrm{mL} \\
0.9-1.8 \mu \mathrm{mol} / \mathrm{L}\end{array}$ & & & [33] \\
\hline Zinc & $\begin{array}{l}0.7-1.6 \mu \mathrm{g} / \mathrm{mL} \\
11-25 \mu \mathrm{mol} / \mathrm{L}\end{array}$ & & & {$[34]$} \\
\hline Iron & $\begin{array}{c}45-160 \mu \mathrm{g} / \mathrm{mL} \\
8-23 \mu \mathrm{mol} / \mathrm{L}\end{array}$ & & $\begin{array}{l}<45 \mu \mathrm{g} / \mathrm{mL} \\
<8 \mu \mathrm{mol} / \mathrm{L}\end{array}$ & [35] \\
\hline
\end{tabular}

*: exact range depends on the laboratory; different cutoff values are used. ${ }^{a}$ : expressed as erythrocyte glutathione reductase activation coefficient (EGRAC). ${ }^{\mathrm{b}}$ : measured as pyridoxal phosphate.

Vitamin D is associated with functional status, illness severity, and prognosis in HF [36]. Vitamin D level positively correlates with cardiopulmonary stress test performance [22] and six-minute walk test distance [37], and negatively with NYHA class $[17,20]$. In a study of severe HF patients, vitamin D concentration was significantly lower in hospitalized subjects requiring intravenous inotropic agents or left ventricular assist devices, compared with those treated as outpatients [22]. Vitamin D also correlates with NT-proANP [19], NT-proBNP [17,38] and left ventricle ejection fraction (LVEF) [20], which are predictors of prognosis in HF. Furthermore, vitamin D levels independently predicted all-cause mortality in an HF study with an 18-month follow-up [38] and strongly predicted mortality in a study with a longer follow-up period of 4 years [36]. Additionally, severe vitamin D deficiency was found as an independent predictor of death due to HF in a study of 3299 enrolled subjects with suspect coronary artery disease [17], and lower levels of vitamin D independently predicts mortality in end-stage HF patients [39].

Although it has been strongly confirmed that vitamin D plays an important role in the development and prognosis of HF, evidence about the effect of vitamin D supplementation in HF patients is inconsistent. It has been documented that vitamin D supplementation (800 IU/day) might protect people $>60$ years from HF [40]. A recent meta-analysis, which included 81 interventional studies with vitamin D supplementation in HF patients, has confirmed a positive effect on cardiovascular risk factors such as high blood pressure, dyslipidemia, and inflammation [41]. Thus, results suggest that the required dose of vitamin D for improvements in risk factors is $\geq 4000 \mathrm{IU}$ (100 g)/day, which is above the tolerable upper intake level for adults and can be associated with toxic side effects $[42,43]$. Supplementation with lower doses ( $\leq 2000 \mathrm{IU} /$ day) in HF patients significantly increased vitamin D levels but had no benefits on LVEF, functional capacity, or quality of life [44,45]. The EVITA, a randomized clinical trial (RCT) that compared vitamin D $4000 \mathrm{IU} /$ day to a placebo in patients with advanced HF and vitamin D deficiency (vitamin $\mathrm{D} \leq 75 \mathrm{nmol} / \mathrm{L}$ ), found no difference in mortality and hospitalization rate. Furthermore, supplementation was associated with a greater need for mechanical circulatory support implant (especially in patients with initial vitamin $D$ concentrations $\geq 30 \mathrm{nmol} / \mathrm{L}$ ) and higher incidence of hypercalcemia [46]. Accordingly, vitamin D supplementation in HF can be considered but requires caution, especially in patients with no evidence of significant deficiency. 


\section{Other Fat-Soluble Vitamins}

Although experimental data have provided evidence that vitamin A regulates the cardiac renin-angiotensin system, and that vitamin A receptors impact the development of diabetes-induced cardiac remodeling and HF in patients with diabetes mellitus [47], the association between vitamin A and HF has not been confirmed in observational studies. Only one study has evaluated vitamin A status in HF, and it found no significant difference between HF patients and sex-matched healthy controls [48]. Dietary vitamin A intake showed no association with HF mortality in the Japan Collaborative Cohort Study, which enrolled 58,696 subjects [49].

Observational studies have found no significant differences in vitamin E status between HF patients and healthy controls $[48,50]$. The same result was found in a rat model of HF [51]. However, in the Japan Collaborative Cohort Study, high dietary intake of vitamin E was associated with a reduced risk of HF mortality in women but not in men [49]. Although vitamin E supplementation ( $400 \mathrm{mg} / \mathrm{day})$ reduces oxidative stress in HF patients [52], it has no impact on symptoms, physical functioning, or mortality [53-56]. Moreover, there are indications that vitamin E treatment may contribute to HF development [54,55].

It is known that vitamin $\mathrm{K}$ status is associated with reduced coronary artery calcification and cardiovascular mortality risk. Vitamin K levels, intake, and supplementation have not been evaluated in HF patients, although epidemiological studies suggest a protective role of vitamin $\mathrm{K}$ in cardiovascular diseases [57].

\section{B Vitamins}

Thiamine (vitamin B1) is a cofactor in the metabolism of carbohydrates and amino acids and is also essential for aerobic metabolism and adenosine triphosphate (ATP) production. Thiamine deficiency is associated with many cardiovascular diseases, including $\mathrm{HF}$, chronic vascular inflammation, myocardial infarction, and conduction defects [58]. Furthermore, the deficiency can cause HF by depriving the heart of ATP [59]. On the other hand, HF induces thiamin deficiency by increasing urinary excretion due to therapy with loop diuretics, and poor absorption of thiamine due to cardiac cachexia and splanchnic congestion $[60,61]$. The addition of spironoloctone to loop diuretics has beneficial effects on thiamine levels in HF patients [62].

The prevalence of thiamine deficiency (Table 2) in HF patients is significantly higher compared with non-HF subjects and ranges from 3\% in ambulatory settings to $91 \%$ in hospital settings [63]. The first observational study that evaluated the effects of thiamine supplementation in HF enrolled only six patients who were treated by intravenous thiamine $(100 \mathrm{mg} /$ day) for 7 days [64]. The results confirmed significant improvement in thiamine levels as assessed by LVEF and NYHA, which encouraged further research, but findings were controversial. An RCT using seven days of intravenous thiamine versus a placebo in a double-blind manner, followed by six weeks of oral thiamine $(200 \mathrm{mg} / \mathrm{day})$ in all patients, indicated significant improvement of LVEF in the thiamine group after seven days (LVEF increase was $4 \%$ ), and impressive improvement of $22 \%$ in all patients at the end of treatment [65]. An RCT with oral thiamine ( $300 \mathrm{mg} /$ day), had a small sample size (18 patients) and a short follow-up period (28 days), but confirmed LVEF improvement after supplementation [66]. However, these results were not confirmed in an RCT that enrolled 52 patients. The main difference between these two RCTs with similar designs was the use of diuretic therapy, which significantly influenced thiamine level. In the trial with no LVEF improvement, the proportion of patients who were on furosemide was low $(<20 \%)$ and spironolactone was prescribed to most patients $(>80 \%)$ in the thiamine group [62]. Oral supplementation may be less effective than intravenous, due to the impaired enteral absorption in HF. Limitations of all performed studies, and potential cause of inconclusive results, included small sample sizes, short follow-up periods, and subjective measures used as endpoints. Accordingly, further research is needed to elucidate the effects of thiamine supplementation on mortality, hospitalization rate, functional status, and quality of life in HF. 
Riboflavin (vitamin B2) is an essential cofactor in cellular energy production, and its deficiency may contribute to the depletion of energy reserves observed in the failing heart. It is water-soluble, has limited tissue storage, and depends on intake (Table 1) and renal excretion. Prevalence of riboflavin deficiency (Table 2) is significantly higher (27\%) in HF patients than in healthy controls $(2.2 \%)[67,68]$. A study on animal models of HF suggests that riboflavin supplementation significantly improves left ventricular systolic and diastolic function [69]. Further research on HF and riboflavin deficiency in humans is required.

Pyridoxine (vitamin B6) plays an important role in intermediary metabolism, as a cofactor mainly in the metabolism of amino acids, but also of carbohydrates and lipids, as well as in the biosynthesis of neurotransmitters. Pyridoxine deficiency (Table 2) prevalence is also higher in HF patients (38\%) than in healthy controls [68]. There are no investigations of isolated pyridoxine supplementation in HF patients.

Cobalamin (vitamin B12) deficiency has been evaluated in the setting of HF, but results are controversial. The largest study evaluating vitamin B12 in HF, with almost 1000 patients, provided unexpected results: vitamin B12 had a weak negative correlation with LVEF and a significant positive correlation with NYHA class [70]. A possible reason for these results is the unclear selection of HF patients: a large number of patients had no systolic dysfunction (mean LVEF were $58 \%$ and $65 \%$ for men and women, respectively) and no clinical manifestations of HF (about 35\% patients were NYHA class I). An observational study found that vitamin B12 deficiency (serum level $<200 \mathrm{pg} / \mathrm{mL}$ ) is relatively rare in $\mathrm{HF}(5 \%)$, and that vitamin $\mathrm{B} 12$ level is not related to prognosis [71]. However, the study was not limited to patients with reduced LVEF, and $13 \%$ of enrolled patients had LVEF $>45 \%$. Although parenteral replacement therapy should be started soon after the vitamin B12 deficiency has been established [72], an interventional study with vitamin B12 supplementation, in addition to folate and vitamin B6, in elderly HF patients (mean age 81 years) suggested no association with NT-proBNP levels [73]. In the future, vitamin B12 should be evaluated in the setting of HF with reduced ejection fraction.

\section{Vitamin C}

Three observational studies $[48,50,74]$ showed significantly lower vitamin $C$ levels among HF patients (mean $39.7 \mu \mathrm{mol} / \mathrm{L}, 61 \mu \mathrm{mol} / \mathrm{L}, 22 \mu \mathrm{mol} / \mathrm{L}$, respectively) than in healthy controls, although in all of them, concentrations were above the cutoff for deficiency (Table 2) [75]. In a more recent study, patients with HF had lower vitamin C levels $(43.3 \mu \mathrm{mol} / \mathrm{L}$ in NYHA II and $46.8 \mu \mathrm{mol} / \mathrm{L}$ in NYHA III/IV) than the control group had $(57.2 \mu \mathrm{mol} / \mathrm{L})$, but the difference was not significant [67]. Two studies, which determined vitamin $C$ deficiency by a 3-day food diary, found a similar prevalence of the dietary deficiency (39\% and $40 \%$, respectively) among HF patients [76,77]. Furthermore, dietary deficiency predicted shorter cardiac event-free survival in both of them. Although some interventional studies have shown that vitamin $C$ supplementation enhances the contractile response to dobutamine [78] and improves endothelial function [79] in HF, there have been no RCTs evaluating vitamin C supplementation in HF. For further research, we propose RCTs that evaluate the effects of vitamin $C$ supplementation on biomarker status, echocardiography parameters, functional status, quality of life, and long-term outcomes in HF patients with confirmed vitamin C deficiency.

\section{Coenzyme Q10}

Coenzyme Q10 (CoQ10) is essential for ATP synthesis, as well as a powerful lipid-soluble antioxidant [80]. Myocardial CoQ10 deficiency has been observed in patients with HF, and it correlates with the severity of symptoms and the LVEF [81]. CoQ10 supplementation also significantly increases its concentration in the blood [82]. Lower levels of CoQ10 (Table 2) are observed in elderly patients and those with more advanced HF [83]. Since 1976, when the first interventional study with CoQ10 administration in HF suggested its therapeutic potential [84], many RCTs have been performed that confirm its benefit in the treatment of HF [85]. CoQ10 significantly improves cardiac output, cardiac 
index, stroke volume, and LVEF $[86,87]$. The administration of CoQ10 in patients with end-stage HF awaiting cardiac transplantation significantly improved functional status, clinical symptoms, and quality of life, but there were no changes in echo parameters [88]. An RCT performed 25 years ago that enrolled $641 \mathrm{HF}$ patients (NYHA class III and IV) demonstrated that the addition of CoQ10 to conventional therapy ( $2 \mathrm{mg} / \mathrm{kg}$ daily for 1 year) significantly reduces hospitalization due to $\mathrm{HF}$ worsening and the incidence of serious complications [89]. The most recent Q-SYMBIO RCT (CoQ10 $100 \mathrm{mg} 3$ times/day for 2 years vs. placebo) confirmed that CoQ10 as an adjunctive treatment of HF is safe, improves symptoms and functional status, and reduces major adverse cardiovascular events, such as death from HF, sudden cardiac death, and hospitalization due to HF worsening [90]. According to all of the above, we suggest that physicians should consider CoQ10 supplementation in advanced $\mathrm{HF}$, especially if the deficiency is confirmed.

\section{Selenium}

Selenium is an essential nutrient and one of the most important antioxidants in the body. It is found within the body in various selenoproteins, such as glutathione peroxidase (GPx), thioredoxin reductase and selenoprotein P [91]. Moreover, selenium has an important role in converting thyroxin into the biologically active triiodothyronine. This may be an additional mechanism by which low concentrations of selenium compromise cardiovascular conditions [92]. The dietary intake of selenium (Table 1) differs throughout the world. In Europe, due to poor selenium content in the soil, the estimated mean intake of selenium (40 $\mu \mathrm{g} /$ day) [93] is significantly lower than the proposed dose for a normal-weighted Caucasian (75 $\mu \mathrm{g} /$ day), which is needed for optimal function of selenoprotein P [94] and cancer protection [33]. Furthermore, it is well known that selenium deficiency may be a cause of reversible HF, a condition known as Keshan Disease [95]. Also, it has been suggested that patients with HF tend to have lower circulating levels of selenium (Table 2) than individuals free from the condition [43]. A case-control-pair longitudinal study with 11,000 enrolled participants found that subjects with low selenium levels have a higher risk for myocardial infarction and cardiovascular mortality [96], but RCTs with selenium supplementation have found no evidence of cardiovascular protection [97].

The metabolism of selenium and CoQ10 are strongly associated with each other, and a deficiency of one can reduce levels or function of the other [98-100]. Accordingly, they are often used and evaluated together. An RCT of an elderly population (mean age 78) who were supplemented with $200 \mu \mathrm{g} / \mathrm{day}$ of organic selenium and $200 \mathrm{mg} /$ day of CoQ10 versus a placebo, found that long-term supplementation reduces NT-proBNP levels and cardiovascular mortality in those with mild to moderate impaired cardiac function [101]. Although an RCT with multiple micronutrient supplementation that included selenium, suggested a beneficial effect on LVEF and quality of life in $30 \mathrm{HF}$ patients (LVEF $\leq 35 \%$, HF due to ischemic heart disease) [102], data about its effects on HF when used alone are insufficient. A recent RCT that compared selenium $200 \mu \mathrm{g} /$ day with a placebo indicated that supplementation for 12 weeks to HF patients has beneficial effects on insulin metabolism and few markers of cardio-metabolic risk [103].

\section{Zinc}

Zinc, which has antioxidant properties [104], is an essential element for humans and is required for enzyme function, multiple signaling pathways and transcription factors, and is also the second most abundant trace metal in humans [105]. Although zinc is widely distributed in human tissue and has numerous functions, it has an important role in controlling cardiac contractility in cardyomyocites [106].

One of the oldest studies on zinc levels in HF patients evaluated zinc status in 20 younger HF patients (34-64 years), and indicated significantly lower levels in subjects with dilated cardiomyopathy than in healthy controls $(74.5 \mu \mathrm{g} / \mathrm{dL}$ or $11.4 \mu \mathrm{mol} / \mathrm{L}$ vs. $93.1 \mu \mathrm{g} / \mathrm{dL}$ or $14.2 \mu \mathrm{mol} / \mathrm{L}$, respectively) [107]. This finding has been supported by studies on patients with LVEF $<40 \%$ and NYHA class II-IV [48,108-110], and finally confirmed by a recent meta-analysis published in 2018 [111]. Moreover, subgroup analysis found that patients with idiopathic dilated cardiomyopathy had lower zinc levels than control subjects, except for patients with ischemic cardiomyopathy. A recent study enrolled 968 
hospitalized patients with decompensated HF who were divided into 3 groups based on serum zinc levels, and found the highest cardiac and all-cause mortality in the third tertile $(<62 \mu \mathrm{g} / \mathrm{dL})$. Serum zinc level was a predictor of cardiac and all-cause mortality, independently of age, gender, comorbidities, medications, other micronutrient levels, B-type natriuretic peptide, and LVEF [112].

Although the role of zinc in cardiovascular medicine has been well represented in molecular research and observational studies in the past few years, there have been no interventional studies or RCTs evaluating zinc supplementation in HF. Two previous studies that included zinc in multiple micronutrient supplements have suggested an association with improvement of cardiac function and quality of life $[103,113]$.

According to the above, further research into zinc supplementation in HF is needed. We propose a study population of elderly patients with advanced HF due to non-ischemic cardiomyopathy and confirmed zinc deficiency, who could have the greatest benefit of the supplementation.

\section{Iron}

Iron is an essential microelement, required for transport, storage and usage of oxygen in humans. In HF, iron deficiency (Table 2) is one of the most common comorbidities, affecting $37-61 \%$ of patients [114-116]. The deficiency, even before the onset of anemia, can be severe among patients with $\mathrm{CHF}$, aggravating symptoms, quality of life, functional status, and clinical outcomes, and is associated with an increased risk of mortality [114,117-120]. The 2016 European Society of Cardiology (ESC) guidelines for the diagnosis and treatment of acute and chronic HF recommend that all patients with HF should be tested for iron deficiency [121]. Moreover, intravenous iron, ferric carboxymaltose, is specifically recommended to be considered for the treatment of iron deficiency in HF, in order to alleviate symptoms and improve exercise capacity and quality of life [122,123]. Oral iron supplementation has no benefit in the setting of HF $[124,125]$ and is not recommended by ESC guidelines. The impaired enteral absorption and other conditions characterized by immune activation are considered as causes for the ineffectiveness of oral iron administration. Findings of the IRONOUT HF RCT (oral iron therapy vs. placebo) [124] are in contrast to results from RCTs of intravenous iron repletion (FAIR-HF and CONFIRM-HF) [122,123], although patient populations were similar. Moreover, in the IRONOUT HF oral therapy produced improvement in iron stores, though the improvement was minimal and clinically not significant.

Iron deficiency is also a frequent co-morbidity in HF with preserved EF (HFpEF), which associated with reduced exercise capacity and quality of life, and its prevalence increases with increasing severity of diastolic dysfunction [126]. Beneficial effects of intravenous iron therapy in an animal model of HFpEF [127] encourage further research, which should elucidate the effects of iron therapy in HF with preserved LVEF.

\section{Conclusions and Future Perspectives}

Although micronutrient deficiencies are frequent among HF patients, their role in pathogenesis and treatment has not yet been completely elucidated. Besides iron supplementation, which is recommended by ESC, CoQ10 supplementation has the strongest evidence of benefit in HF. The available data suggest consideration of vitamin D supplementation in cases of confirmed deficiency in patients with HF. Some micronutrients (selenium, zinc, vitamin B2, and vitamin B6) showed improvement of various clinical parameters in HF, but were investigated only in a multiple supplementation setting, while the effects of vitamins B1 and B12 were inconsistent due to unclear selection of patients and poorly defined endpoints. The influence of vitamin C supplementation in HF is yet to be determined. Thus, interventional studies with strict selection criteria and clear endpoints for each micronutrient are still needed to gain better insight into their role in HF. Furthermore, the question remains as to whether the deficiency cutoff values drawn from the general population apply to HF patients; this should be addressed in future research. Supplementation trials should take into account reduced food intake and poor intestinal absorption of nutrients in these patients, and should investigate not only dosage with beneficial effects, 
but also the routes of administration (i.e., oral or intravenous). In addition, the available data on micronutrient supplementation in patients with HFpEF are scarce and should be thoroughly researched in the future.

Funding: The authors acknowledge the projects (Epidemiology, patophysiology and clinical significance of iron deficiency in chronic cardiopulmonary disease; ID J3-9284 and Burden of cachexia and sarcopenia in patients with chronic diseases: epidemiology, pathophysiology and outcomes; ID J3-9292) were financially supported by the Slovenian Research Agency.

Conflicts of Interest: The autohors declare no conflict of interest.

\section{References}

1. Braunwald, E. Heart Failure. JACC Hear. Fail. 2013, 1, 1-20. [CrossRef] [PubMed]

2. Cvetinovic, N.; Loncar, G.; Farkas, J. Heart failure management in the elderly-A public health challenge. Wien. Klin. Wochenschr. 2016, 128, 466-473. [CrossRef] [PubMed]

3. Wong, A.-P.; Niedzwiecki, A.; Rath, M. Myocardial energetics and the role of micronutrients in heart failure: A critical review. Am. J. Cardiovasc. Dis. 2016, 15, 81-92.

4. Witte, K.K.; Clark, A.L. Micronutrients and their supplementation in chronic cardiac failure. An update beyond theoretical perspectives. Heart Fail. Rev. 2006, 11, 65-74. [CrossRef] [PubMed]

5. Ross, A.C.; Taylor, C.L.; Yaktine, A.L.; del Valle, H.B. Dietary Reference Values for Vitamin D; National Academies Press: Washington, DC, USA, 2016.

6. Ross, A.C.; Taylor, C.L.; Yaktine, A.L.; del Valle, H.B. Dietary Reference Intakes for Calcium and Vitamin, D; National Academies Press: Washington, DC, USA, 2011.

7. Ross, A.C.; Taylor, C.L.; Yaktine, A.L.; del Valle, H.B. Dietary Reference Intakes for Thiamin, Riboflavin, Niacin, Vitamin B6, Folate, Vitamin B12, Pantothenic Acid, Biotin, and Choline; National Academies Press: Washington, DC, USA, 1998.

8. Ross, A.C.; Taylor, C.L.; Yaktine, A.L.; del Valle, H.B. Dietary Reference Intakes; National Academies Press: Washington, DC, USA, 2003.

9. Said, H.M. Water-Soluble Vitamins. World Rev. Nutr. Diet. 2014, 111, 30-37. [PubMed]

10. Ross, A.C.; Taylor, C.L.; Yaktine, A.L.; del Valle, H.B. Dietary Reference Intakes for Vitamin C, Vitamin E, Selenium, and Carotenoids; National Academies Press: Washington, DC, USA, 2000.

11. Ross, A.C.; Taylor, C.L.; Yaktine, A.L.; del Valle, H.B. Dietary Reference Intakes for Vitamin A, Vitamin K, Arsenic, Boron, Chromium, Copper, Iodine, Iron, Manganese, Molybdenum, Nickel, Silicon, Vanadium, and Zinc; National Academies Press: Washington, DC, USA, 2001.

12. Wimalawansa, S.J.; Razzaque, M.S.; Al-Daghri, N.M. Calcium and vitamin D in human health: Hype or real? J. Steroid Biochem. Mol. Biol. 2018, 180, 4-14. [CrossRef] [PubMed]

13. Zeljic, K.; Kandolf-Sekulovic, L.; Supic, G.; Pejovic, J.; Novakovic, M.; Mijuskovic, Z. Melanoma risk is associated with vitamin D receptor gene polymorphisms. Melanoma Res. 2014, 24, 273-279. [CrossRef] [PubMed]

14. Parker, J.; Hashmi, O.; Dutton, D.; Mavrodaris, A.; Stranges, S.; Kandala, N.B.; Clarke, A.; Franco, O.H. Levels of vitamin D and cardiometabolic disorders: Systematic review and meta-analysis. Maturitas 2010, 65, 225-236. [CrossRef] [PubMed]

15. Kim, D.H.; Sabour, S.; Sagar, U.N.; Adams, S.; Whellan, D.J. Prevalence of Hypovitaminosis D in Cardiovascular Diseases (from the National Health and Nutrition Examination Survey 2001 to 2004). Am. J. Cardiol. 2008, 102, 1540-1544. [CrossRef] [PubMed]

16. Anderson, J.L.; May, H.T.; Horne, B.D.; Bair, T.L.; Hall, N.L.; Carlquist, J.F.; Lappé, D.L.; Muhlestein, J.B. Relation of vitamin D deficiency to cardiovascular risk factors, disease status, and incident events in a general healthcare population. Am. J. Cardiol. 2010, 106, 963-968. [CrossRef] [PubMed]

17. Wellnitz, B.; Seelhorst, U.; Dimai, H.P.; Dobnig, H.; Pilz, S.; Maäz, W.; Fahrleitner-Pammer, A.; Boehm, B.O. Association of vitamin $\mathrm{D}$ deficiency with heart failure and sudden cardiac death in a large cross-sectional study of patients referred for coronary angiography. J. Clin. Endocrinol. Metab. 2008, 93, 3927-3935.

18. Song, E.K.; Kang, S.M. Micronutrient Deficiency Independently Predicts Adverse Health Outcomes in Patients with Heart Failure. J. Cardiovasc. Nurs. 2017, 32, 47-53. [CrossRef] [PubMed] 
19. Zittermann, A.; Schulze Schleithoff, S.; Tenderich, G.; Berthold, H.K.; Körfer, R.; Stehle, P. Low vitamin D status: A contributing factor in the pathogenesis of congestive heart failure? J. Am. Coll. Cardiol. 2003, 41, 105-112. [CrossRef]

20. Ameri, P.; Ronco, D.; Casu, M.; Denegri, A.; Bovio, M.; Menoni, S.; Ferone, D.; Murialdo, G. High prevalence of vitamin $\mathrm{D}$ deficiency and its association with left ventricular dilation: An echocardiography study in elderly patients with chronic heart failure. Nutr. Metab. Cardiovasc. Dis. 2010, 20, 633-640. [CrossRef] [PubMed]

21. Loncar, G.; Bozic, B.; Cvetinovic, N.; Dungen, H.D.; Lainscak, M.; von Haehling, S.; Doehner, W.; Radojicic, Z.; Putnikovic, B.; Trippel, T.; et al. Secondary hyperparathyroidism prevalence and prognostic role in elderly males with heart failure. J. Endocrinol. Investig. 2017, 40, 297-304. [CrossRef] [PubMed]

22. Shane, E.; Mancini, D.; Aaronson, K.; Silverberg, S.J.; Seibel, M.J.; Addesso, V.; McMahon, D.J. Bone mass, vitamin D deficiency, and hyperparathyroidism in congestive heart failure. Am. J. Med. 1997, 103, $197-207$. [CrossRef]

23. Holick, M.F. The vitamin D deficiency pandemic: Approaches for diagnosis, treatment and prevention. Rev. Endocr. Metab. Disord. 2017, 18, 153-165. [CrossRef] [PubMed]

24. Whitfield, K.C.; Bourassa, M.W.; Adamolekun, B.; Bergeron, G.; Bettendorff, L.; Brown, K.H.; Cox, L.; Fattal-Valevski, A.; Fischer, P.R.; Frank, E.L.; et al. Thiamine deficiency disorders: Diagnosis, prevalence, and a roadmap for global control programs. Ann. N. Y. Acad. Sci. 2018, 1430,3-43. [CrossRef] [PubMed]

25. Hill, M.H.E.; Bradley, A.; Mushtaq, S.; Williams, E.A.; Powers, H.J. Effects of methodological variation on assessment of riboflavin status using the erythrocyte glutathione reductase activation coefficient assay. Br. J. Nutr. 2009, 102, 273. [CrossRef] [PubMed]

26. McPherson, R.A.; Pincus, M.R. Henry's Clinical Diagnosis and Management by Laboratory Methods; Elsevier: Amsterdam, Switzerland, 2016.

27. Leklem, J.E. Vitamin B-6: A Status Report. J. Nutr. 1990, 120, 1503-1507. [CrossRef] [PubMed]

28. Panton, K.K.; Farup, P.G.; Sagen, E.; Sirum, U.F.; Åsberg, A. Vitamin B6 in plasma-Sample stability and the reference limits. Scand. J. Clin. Lab. Investig. 2013, 73, 476-479. [CrossRef] [PubMed]

29. Hunt, A.; Harrington, D.; Robinson, S. Vitamin B12 deficiency. BMJ 2014, 349, g5226. [CrossRef] [PubMed]

30. Klee, G.G. Cobalamin and folate evaluation: Measurement of methylmalonic acid and homocysteine vs. vitamin B(12) and folate. Clin. Chem. 2000, 46, 1277-1283. [PubMed]

31. Scientific Opinion on Dietary Reference Values for vitamin C. EFSA J. 2013, 11, 3418. [CrossRef]

32. Molyneux, S.L.; Young, J.M.; Florkowski, C.M.; Lever, M.; George, P.M. Coenzyme Q10: Is there a clinical role and a case for measurement? Clin. Biochem. Rev. 2008, 29, 71-82. [PubMed]

33. Thomson, C.D. Assessment of requirements for selenium and adequacy of selenium status: A review. Eur. J. Clin. Nutr. 2004, 58, 391-402. [CrossRef] [PubMed]

34. Livingstone, C. Zinc: Physiology, deficiency, and parenteral nutrition. Nutr. Clin. Pract. 2015, 30, $371-382$. [CrossRef] [PubMed]

35. Gomella, L.G.; Haist, S.A. Clinician's Pocket Reference; University of Kentucky, College of Medicine, McGraw-Hill Companies, Inc: New York, NY, USA, 2007.

36. Gruson, D.; Ferracin, B.; Ahn, S.A.; Zierold, C.; Blocki, F.; Hawkins, D.M.; Bonelli, F.; Rousseau, M.F. 1,25-Dihydroxyvitamin D to PTH(1-84) ratios strongly predict cardiovascular death in heart failure. PLoS ONE 2015, 10, e0135427. [CrossRef] [PubMed]

37. Boxer, R.S.; Dauser, D.A.; Walsh, S.J.; Hager, W.D.; Kenny, A.M. The association between vitamin D and inflammation with the 6-minute walk and frailty in patients with heart failure. J. Am. Geriatr. Soc. 2008, 56, 454-461. [CrossRef] [PubMed]

38. Liu, L.C.Y.; Voors, A.A.; Van Veldhuisen, D.J.; Van Der Veer, E.; Belonje, A.M.; Szymanski, M.K.; Silljé, H.H.; Van Gilst, W.H.; Jaarsma, T.; De Boer, R.A. Vitamin D status and outcomes in heart failure patients. Eur. J. Heart Fail. 2011, 13, 619-625. [CrossRef] [PubMed]

39. Zittermann, A.; Schleithoff, S.S.; Götting, C.; Dronow, O.; Fuchs, U.; Kühn, J.; Kleesiek, K.; Tenderich, G.; Koerfer, R. Poor outcome in end-stage heart failure patients with low circulating calcitriol levels. Eur. J. Heart Fail. 2008, 10, 321-327. [CrossRef] [PubMed]

40. Ford, J.A.; MacLennan, G.S.; Avenell, A.; Bolland, M.; Grey, A.; Witham, M. Cardiovascular disease and vitamin D supplementation: Trial analysis, systematic review, and meta-analysis. Am. J. Clin. Nutr. 2014, 100, 746-755. [CrossRef] [PubMed] 
41. Mirhosseini, N.; Rainsbury, J.; Kimball, S.M. Vitamin D Supplementation, Serum 25(OH)D Concentrations and Cardiovascular Disease Risk Factors: A Systematic Review and Meta-Analysis. Front. Cardiovasc. Med. 2018, 5, 87. [CrossRef] [PubMed]

42. Ross, A.C.; Manson, J.E.; Abrams, S.A.; Aloia, J.F.; Brannon, P.M.; Clinton, S.K.; Durazo-Arvizu, R.A.; Gallagher, J.C.; Gallo, R.L.; Jones, G.; et al. The 2011 Dietary Reference Intakes for Calcium and Vitamin D: What Dietetics Practitioners Need to Know. J. Am. Diet. Assoc. 2011, 111, 524-527. [CrossRef] [PubMed]

43. McKeag, N.A.; McKinley, M.C.; Woodside, J.V.; Harbinson, M.T.; McKeown, P.P. The Role of Micronutrients in Heart Failure. J. Acad. Nutr. Diet. 2012, 112, 870-886. [CrossRef] [PubMed]

44. Schleithoff, S.S.; Zittermann, A.; Tenderich, G.; Berthold, H.K.; Stehle, P.; Koerfer, R. Vitamin D supplementation improves cytokine profiles in patients with congestive heart failure: A double-blind, randomized, placebo-controlled trial. Am. J. Clin. Nutr. 2006, 83, 754-759. [CrossRef] [PubMed]

45. Witham, M.D.; Crighton, L.J.; Gillespie, N.D.; Struthers, A.D.; McMurdo, M.E.T. The effects of vitamin D supplementation on physical function and quality of life in older patients with heart failure a randomized controlled trial. Circ. Heart Fail. 2010, 3, 195-201. [CrossRef] [PubMed]

46. Zittermann, A.; Ernst, J.B.; Prokop, S.; Fuchs, U.; Dreier, J.; Kuhn, J.; Knabbe, C.; Birschmann, I.; Schulz, U.; Berthold, H.K.; et al. Effect of Vitamin D on all-causemortality in heart failure (EVITA): A 3-year randomized clinical trial with 4000 IU Vitamin D daily. Eur. Heart J. 2017, 38, 2279-2286. [CrossRef] [PubMed]

47. Pan, J.; Guleria, R.; Zhu, S.; Baker, K. Molecular Mechanisms of Retinoid Receptors in Diabetes-Induced Cardiac Remodeling. J. Clin. Med. 2014, 4, 566-594. [CrossRef] [PubMed]

48. De Lorgeril, M.; Salen, P.; Accominotti, M.; Cadau, M.; Steghens, J.-P.; Boucher, F.; De Leiris, J. Dietary and blood ANTIOXIDANTS in patients with chronic heart failure. Insights into the potential importance of selenium in heart failure. Eur. J. Heart Fail. 2001, 3, 661-669. [CrossRef]

49. Eshak, E.S.; Iso, H.; Yamagishi, K.; Cui, R.; Tamakoshi, A. Dietary intakes of fat soluble vitamins as predictors of mortality from heart failure in a large prospective cohort study. Nutrition 2018, 47, 50-55. [CrossRef] [PubMed]

50. Keith, M.; Geranmayegan, A.; Sole, M.J.; Kurian, R.; Robinson, A.; Omran, A.S.; Jeejeebhoy, K.N. Increased oxidative stress in patients with congestive heart failure. J. Am. Coll. Cardiol. 1998, 31, 1352-1356. [CrossRef]

51. Marcocci, L.; Suzuki, Y.J. Metabolomics studies to assess biological functions of vitamin E nicotinate. Antioxidants 2019, 8, 127. [CrossRef] [PubMed]

52. Ghatak, A.; Brar, M.J.S.; Agarwal, A.; Goel, N.; Rastogi, A.K.; Vaish, A.K.; Sircar, A.R.; Chandra, M. Oxy free radical system in heart failure and therapeutic role of oral vitamin E. Int. J. Cardiol. 1996, 57, 119-127. [CrossRef]

53. Yusuf, S.; Dagenais, G.; Pogue, J.; Bosch, J.; Sleight, P. Vitamin E supplementation and cardiovascular events in high-risk patients. The Heart Outcomes Prevention Evaluation Study Investigators. N. Engl. J. Med. 2000, 342, 154-160. [PubMed]

54. Lonn, E. Effects of long-term vitamin E supplementation on cardiovascular events and cancer: A randomized controlled trial. J. Am. Med. Assoc. 2005, 293, 1338-1347.

55. Marchioli, R.; Levantesi, G.; Macchia, A.; Marfisi, R.M.; Nicolosi, G.L.; Tavazzi, L.; Tognoni, G.; Valagussa, F. Vitamin $\mathrm{E}$ increases the risk of developing heart failure after myocardial infarction: Results from the GISSI-Prevenzione trial. J. Cardiovasc. Med. 2006, 7, 347-350. [CrossRef] [PubMed]

56. E Keith, M.; Jeejeebhoy, K.N.; Langer, A.; Kurian, R.; Barr, A.; O’Kelly, B.; Sole, M.J. A controlled clinical trial of vitamin E supplementation in patients with congestive heart failure. Am. J. Clin. Nutr. 2001, 73, 219-224. [CrossRef] [PubMed]

57. Tsugawa, N. Cardiovascular diseases and fat soluble vitamins: Vitamin D and vitamin K. J. Nutr. Sci. Vitam. (Tokyo) 2015, 61, S170-S172. [CrossRef] [PubMed]

58. Eshak, E.S.; Arafa, A.E. Thiamine deficiency and cardiovascular disorders. Nutr. Metab. Cardiovasc. Dis. 2018, 28, 965-972. [CrossRef] [PubMed]

59. Attaluri, P.; Castillo, A.; Edriss, H.; Nugent, K. Thiamine Deficiency: An Important Consideration in Critically Ill Patients. Am. J. Med. Sci. 2018, 356, 382-390. [CrossRef] [PubMed]

60. Zenuk, C.; Healey, J.; Donnelly, J.; Vaillancourt, R.; Almalki, Y.; Smith, S. Thiamine deficiency in congestive heart failure patients receiving long term furosemide therapy. Can J. Clin. Pharmacol. 2003, 10, 184-188. [PubMed] 
61. Kattoor, A.J.; Goel, A.; Mehta, J.L. Thiamine Therapy for Heart Failure: A Promise or Fiction? Cardiovasc. Drugs Ther. 2018, 32, 313-317. [CrossRef] [PubMed]

62. Rocha, R.M.; Silva, G.V.; de Albuquerque, D.C.; Tura, B.R.; Albanesi Filho, F.M. Influence of spironolactone therapy on thiamine blood levels in patients with heart failure. Arq. Bras. Cardiol. 2008, 90, 324-328. [PubMed]

63. Jain, A.; Mehta, R.; Al-Ani, M.; Hill, J.A.; Winchester, D.E. Determining the Role of Thiamine Deficiency in Systolic Heart Failure: A Meta-Analysis and Systematic Review. J. Card. Fail. 2015, 21, 1000-1007. [CrossRef] [PubMed]

64. Seligmann, H.; Halkin, H.; Rauchfleisch, S.; Kaufmann, N.; Tal, R.; Motro, M.; Vered, Z.; Ezra, D. Thiamine deficiency in patients with congestive heart failure receiving long-term furosemide therapy: A pilot study. Am. J. Med. 1991, 91, 151-155. [CrossRef]

65. Shimon, H.; Almog, S.; Vered, Z.; Seligmann, H.; Shefi, M.; Peleg, E.; Rosenthal, T.; Motro, M.; Halkin, H.; Ezra, D. Improved left ventricular function after thiamine supplementation in patients with congestive heart failure receiving long-term furosemide therapy. Am. J. Med. 1995, 98, 485-490. [CrossRef]

66. Schoenenberger, A.W.; Schoenenberger-Berzins, R.; Der Maur, C.A.; Suter, P.M.; Vergopoulos, A.; Erne, P. Thiamine supplementation in symptomatic chronic heart failure: A randomized, double-blind, placebo-controlled, cross-over pilot study. Clin. Res. Cardiol. 2012, 101, 159-164. [CrossRef] [PubMed]

67. Hughes, C.M.; Woodside, J.V.; McGartland, C.; Roberts, M.J.; Nicholls, D.P.; McKeown, P.P. Nutritional intake and oxidative stress in chronic heart failure. Nutr. Metab. Cardiovasc. Dis. 2012, 22, 376-382. [CrossRef] [PubMed]

68. Keith, M.E.; Walsh, N.A.; Darling, P.B.; Hanninen, S.A.; Thirugnanam, S.; Leong-Poi, H.; Barr, A.; Sole, M.J. B-Vitamin Deficiency in Hospitalized Patients with Heart Failure. J. Am. Diet. Assoc. 2009, 109, 1406-1410. [CrossRef] [PubMed]

69. Wang, G.; Li, W.; Lu, X.; Zhao, X. Riboflavin Alleviates Cardiac Failure in Type I Diabetic Cardiomyopathy. Heart Int. 2011, 6, e21. [CrossRef] [PubMed]

70. Herrmann, M.; Müller, S.; Kindermann, I.; Günther, L.; König, J.; Böhm, M.; Herrmann, W. Plasma B vitamins and their relation to the severity of chronic heart failure. Am. J. Clin. Nutr. 2007, 85, 117-123. [CrossRef] [PubMed]

71. Van Der Wal, H.H.; Comin-Colet, J.; Klip, I.T.; Enjuanes, C.; Beverborg, N.G.; Voors, A.A.; Banasiak, W.; van Veldhuisen, D.J.; Bruguera, J.; Ponikowski, P.; et al. Vitamin B12 and folate deficiency in chronic heart failure. Heart 2015, 101, 302-310. [CrossRef] [PubMed]

72. Briani, C.; Torre, C.D.; Citton, V.; Manara, R.; Pompanin, S.; Binotto, G.; Adami, F. Cobalamin deficiency: Clinical picture and radiological findings. Nutrients 2013, 5, 4521-4539. [CrossRef] [PubMed]

73. Andersson, S.E.; Edvinsson, M.L.; Edvinsson, L. Reduction of homocysteine in elderly with heart failure improved vascular function and blood pressure control but did not affect inflammatory activity. Basic Clin. Pharmacol. Toxicol. 2005, 97, 306-310. [CrossRef] [PubMed]

74. Demirbag, R.; Yilmaz, R.; Erel, O.; Gultekin, U.; Asci, D.E.Z. The relationship between potency of oxidative stress and severity of dilated cardiomyopathy. Can. J. Cardiol. 2005, 21, 851-855. [PubMed]

75. Jacob, R. Assessment of human vitamin C status. J. Nutr. 1990, 11, 1480-1485. [CrossRef] [PubMed]

76. Song, E.K.; Kang, S.M. Vitamin C Deficiency, High-Sensitivity C-Reactive Protein, and Cardiac Event-Free Survival in Patients with Heart Failure. J. Cardiovasc. Nurs. 2018, 33, 6-12. [CrossRef] [PubMed]

77. Wu, J.-R.; Song, E.K.; Moser, D.K.; Lennie, T.A. Dietary Vitamin C Deficiency Is Associated With Health-Related Quality of Life and Cardiac Event-free Survival in Adults With Heart Failure. J. Cardiovasc. Nurs. 2018, 34, 29-35. [CrossRef] [PubMed]

78. Shinke, T.; Shite, J.; Takaoka, H.; Hata, K.; Inoue, N.; Yoshikawa, R.; Matsumoto, H.; Masai, H.; Watanabe, S.; Ozawa, T.; et al. Vitamin $\mathrm{C}$ restores the contractile response to dobutamine and improves myocardial efficiency in patients with heart failure after anterior myocardial infarction. Am. Heart J. 2007, 154, e1-e8. [CrossRef] [PubMed]

79. Hornig, B.; Arakawa, N.; Kohler, C.; Drexler, H. Vitamin C improves endothelial function of conduit arteries in patients with chronic heart failure. Circulation 1998, 97, 363-368. [CrossRef] [PubMed]

80. Bentinger, M.; Brismar, K.; Dallner, G. The antioxidant role of coenzyme Q. Mitochondrion 2007, 7, S41-S50. [CrossRef] [PubMed]

81. Folkers, K.; Vadhanavikit, S.; Mortensent, S.A. Biochemical rationale and myocardial tissue data on the effective therapy of cardiomyopathy with coenzyme Q10. Med. Sci. 1985, 82, 901-904. [CrossRef] [PubMed] 
82. Madmani, M.E.; Yusuf Solaiman, A.; Tamr Agha, K.; Madmani, Y.; Shahrour, Y.; Essali, A.; Kadro, W. Coenzyme Q10 for heart failure. Cochrane Database Syst. Rev. 2014, 2, CD008684. [CrossRef] [PubMed]

83. McMurray, J.J.V.; Dunselman, P.; Wedel, H.; Cleland, J.G.F.; Lindberg, M.; Hjalmarson, A.; Kjekshus, J.; Waagstein, F.; Apetrei, E.; Barrios, V.; et al. Coenzyme Q10, rosuvastatin, and clinical outcomes in heart failure: A pre-specified substudy of CORONA (Controlled Rosuvastatin Multinational Study in Heart Failure). J. Am. Coll. Cardiol. 2010, 56, 1196-1204. [CrossRef] [PubMed]

84. Ishiyama, T.; Morita, Y.; Toyama, S.; Yamagami, T.; Tsukamoto, N. A clinical study of the effect of coenzyme $\mathrm{Q}$ on congestive heart failure. Jpn. Heart J. 1976, 17, 32-42. [CrossRef] [PubMed]

85. Jafari, M.; Mousavi, S.M.; Asgharzadeh, A.; Yazdani, N. Coenzyme Q10 in the treatment of heart failure: A systematic review of systematic reviews. Indian Heart J. 2018, 70, S111-S117. [CrossRef] [PubMed]

86. Sander, S.; Coleman, C.I.; Patel, A.A.; Kluger, J.; Michael White, C. The Impact of Coenzyme Q10 on Systolic Function in Patients With Chronic Heart Failure. J. Card. Fail. 2006, 12, 464-472. [CrossRef] [PubMed]

87. Rosenfeldt, F.; Hilton, D.; Pepe, S.; Krum, H. Systematic review of effect of coenzyme Q10 in physical exercise, hypertension and heart failure. Biofactors 2003, 18, 91-100. [CrossRef] [PubMed]

88. Sinatra, S.T.; Berman, M. Coenzyme Q10 in patients with end-stage heart failure awaiting cardiac transplantation: A randomized, placebo-controlled study. Clin. Cardiol. 2004, 27, A26-A30. Coenzyme Q10 in patients with end-stage heart failure awaiting cardiac transplantation: A randomized, placebo-controlled study. Clin. Cardiol. 2004, 27, 295-299.

89. Morisco, C.; Trimarco, B.; Condorelli, M. Effect of coenzyme Q10therapy in patients with congestive heart failure: A long-term multicenter randomized study. Clin. Investig. 1993, 71, S134-S136. [CrossRef] [PubMed]

90. Mortensen, S.A.; Rosenfeldt, F.; Kumar, A.; Dolliner, P.; Filipiak, K.J.; Pella, D.; Alehagen, U.; Steurer, G.; Littarru, G.P. Q-SYMBIO Study Investigators. The effect of coenzyme Q10on morbidity and mortality in chronic heart failure: Results from Q-SYMBIO: A randomized double-blind trial. JACC Hear Fail. 2014, 2, 641-649. [CrossRef] [PubMed]

91. Fairweather-Tait, S.J.; Bao, Y.; Broadley, M.R.; Collings, R.; Ford, D.; Hesketh, J.E.; Hurst, R. Selenium in Human Health and Disease. Antioxid. Redox Signal. 2011, 14, 1337-1383. [CrossRef] [PubMed]

92. de Lorgeril, M.; Salen, P. Selenium and antioxidant defenses as major mediators in the development of chronic heart failure. Heart Fail. Rev. 2006, 11, 13-17. [CrossRef] [PubMed]

93. Rayman, M.P. Selenium and human health. Lancet 2012, 379, 1256-1268. [CrossRef]

94. Xia, Y.; E Hill, K.; Li, P.; Xu, J.; Zhou, D.; Motley, A.K.; Wang, L.; Byrne, D.W.; Burk, R.F. Optimization of selenoprotein $\mathrm{P}$ and other plasma selenium biomarkers for the assessment of the selenium nutritional requirement: A placebo-controlled, double-blind study of selenomethionine supplementation in selenium-deficient Chinese subjects. Am. J. Clin. Nutr. 2010, 92, 525-531. [CrossRef] [PubMed]

95. Ge, K.; Yang, G. The epidemiology of selenium deficiency in the etiological study of endemic diseases in China. Am. J. Clin. Nutr. 1993, 57, 259S-263S. [CrossRef] [PubMed]

96. Salonen, J.T.; Alfthan, G.; Huttunen, J.K.; Pikkarainen, J.; Puska, P. Association between cardiovascular death and myocardial infarction and serum selenium in a matched-pair longitudinal study. Lancet 1982, 2, 175-179. [CrossRef]

97. Navas-Acien, A.; Bleys, J.; Guallar, E. Selenium intake and cardiovascular risk: What is new? Curr. Opin. Lipidol. 2008, 19, 43-49. [CrossRef] [PubMed]

98. Nordman, T.; Xia, L.; Björkhem-Bergman, L.; Damdimopoulos, A.; Nalvarte, I.; Arnér, E.S.J.; Spyrou, G.; Eriksson, L.C.; Björnstedt, M.; Olsson, J.M. Regeneration of the antioxidant ubiquinol by lipoamide dehydrogenase, thioredoxin reductase and glutathione reductase. Biofactors 2003, 18, 45-50. [CrossRef] [PubMed]

99. Moosmann, B.; Behl, C. Selenoproteins, cholesterol-lowering drugs, and the consequences: Revisiting of the mevalonate pathway. Trends Cardiovasc. Med. 2004, 14, 273-281. [CrossRef] [PubMed]

100. Alehagen, U.; Aaseth, J. Selenium and coenzyme Q10 interrelationship in cardiovascular diseases-A clinician's point of view. J. Trace Elem. Med. Biol. 2015, 31, 157-162. [CrossRef] [PubMed]

101. Johansson, P.; Dahlström, Ö.; Dahlström, U.; Alehagen, U. Effect of selenium and Q10 on the cardiac biomarker NT-proBNP. Scand Cardiovasc. J. 2013, 47, 281-288. [CrossRef] [PubMed]

102. Witte, K.K.; Nikitin, N.P.; Parker, A.C.; Von Haehling, S.; Volk, H.-D.; Anker, S.D.; Clark, A.L.; Cleland, J.G. The effect of micronutrient supplementation on quality-of-life and left ventricular function in elderly patients with chronic heart failure. Eur. Heart J. 2005, 26, 2238-2244. [CrossRef] [PubMed] 
103. Raygan, F.; Behnejad, M.; Ostadmohammadi, V.; Bahmani, F.; Mansournia, M.A.; Karamali, F.; Asemi, Z. Selenium supplementation lowers insulin resistance and markers of cardio-metabolic risk in patients with congestive heart failure: A randomised, double-blind, placebo-controlled trial. Br. J. Nutr. 2018, 120, 33-40. [CrossRef] [PubMed]

104. Vasto, S.; Mocchegiani, E.; Candore, G.; Listì, F.; Colonna-Romano, G.; Lio, D.; Malavolta, M.; Giacconi, R.; Cipriano, C.; Caruso, C. Inflammation, genes and zinc in ageing and age-related diseases. Biogerontology 2006, 7, 315-327. [CrossRef] [PubMed]

105. Cherasse, Y.; Urade, Y. Dietary zinc acts as a sleep modulator. Int. J. Mol. Sci. 2017, 18, 2334. [CrossRef] [PubMed]

106. Turan, B.; Tuncay, E. Impact of labile zinc on heart function: From physiology to pathophysiology. Int. J. Mol. Sci. 2017, 18, 2395. [CrossRef] [PubMed]

107. Oster, O. Trace element concentrations $(\mathrm{Cu}, \mathrm{Zn}, \mathrm{Fe})$ in sera from patients with dilated cardiomyopathy. Clin. Chim. Acta 1993, 214, 209-218. [CrossRef]

108. Ripa, S.; Ripa, R.; Giustiniani, S. Are failured cardiomyopathies a zinc-deficit related disease? A study on Zn and $\mathrm{Cu}$ in patients with chronic failured dilated and hypertrophic cardiomyopathies. Minerva Med. 1998, 89, 397-403. [PubMed]

109. Topuzoglu, G.; Erbay, A.R.; Karul, A.B.; Yensel, N. Concentations of Copper, Zinc, and Magnesium in Sera from Patients with Idiopathic Dilated Cardiomyopathy. Biol. Trace Elem. Res. 2003, 95, 11-17. [CrossRef]

110. Koşar, F.; Sahin, I.; Taşkapan, C.; Küçükbay, Z.; Güllü, H.; Taşkapan, H.; Cehreli, S. Trace element status (Se, Zn, Cu) in heart failure. Anadolu Kardiyol. Derg. 2006, 6, 216-220. [PubMed]

111. Yu, X.; Huang, L.; Zhao, J.; Wang, Z.; Yao, W.; Wu, X.; Huang, J.; Bian, B. The Relationship between Serum Zinc Level and Heart Failure: A Meta-Analysis. Biomed Res Int. 2018, 2018, 1-9. [CrossRef] [PubMed]

112. Yoshihisa, A.; Abe, S.; Kiko, T.; Kimishima, Y.; Sato, Y.; Watanabe, S.; Kanno, Y.; Miyata-Tatsumi, M.; Misaka, T.; Sato, T.; et al. Association of Serum Zinc Level With Prognosis in Patients With Heart Failure. J. Card Fail. 2018, 24, 375-383. [CrossRef] [PubMed]

113. Jeejeebhoy, F.; Keith, M.; Freeman, M.; Barr, A.; McCall, M.; Kurian, R.; Mazer, D.; Errett, L. Nutritional supplementation with MyoVive repletes essential cardiac myocyte nutrients and reduces left ventricular size in patients with left ventricular dysfunction. Am. Heart J. 2002, 143, 1092-1100. [CrossRef] [PubMed]

114. Jankowska, E.A.; Rozentryt, P.; Witkowska, A.; Nowak, J.; Hartmann, O.; Ponikowska, B.; Borodulin-Nadzieja, L.; Banasiak, W.; Polonski, L.; Filippatos, G.; et al. Iron deficiency: An ominous sign in patients with systolic chronic heart failure. Eur. Heart J. 2010, 31, 1872-1880. [CrossRef] [PubMed]

115. Peyrin-Biroulet, L.; Williet, N.; Cacoub, P. Guidelines on the diagnosis and treatment of iron deficiency across indications: A systematic review. Am. J. Clin. Nutr. 2015, 102, 1585-1594. [CrossRef] [PubMed]

116. Klip, I.T.; Comín-Colet, J.; Voors, A.A.; Ponikowski, P.; Enjuanes, C.; Banasiak, W.; Lok, D.J.; Rosentryt, P.; Torrens, A.; Polonski, L.; et al. Iron deficiency in chronic heart failure: An international pooled analysis. Am. Heart J. 2013, 165, 575-582.e3. [CrossRef] [PubMed]

117. Jankowska, E.A.; Von Haehling, S.; Anker, S.D.; MacDougall, I.C.; Ponikowski, P. Iron deficiency and heart failure: Diagnostic dilemmas and therapeutic perspectives. Eur. Heart J. 2013, 34, 816-829. [CrossRef] [PubMed]

118. Anker, S.D.; Kirwan, B.A.; van Veldhuisen, D.J.; Filippatos, G.; Comin-Colet, J.; Ruschitzka, F.; Lüscher, T.F.; Arutyunov, G.P.; Motr, M.; Mori, C.; et al. Effects of ferric carboxymaltose on hospitalisations and mortality rates in iron-deficient heart failure patients: An individual patient data meta-analysis. Eur. J. Heart Fail. 2018, 20, 125-133. [CrossRef] [PubMed]

119. Enjuanes, C.; Bruguera, J.; Grau, M.; Cladellas, M.; Gonzalez, G.; Meroño, O.; Moliner-Borja, P.; Verdú, J.M.; Farré, N.; Comín-Colet, J. Iron Status in Chronic Heart Failure: Impact on Symptoms, Functional Class and Submaximal Exercise Capacity. Rev. Esp. Cardiol. (Engl. Ed) 2016, 69, 247-255. [CrossRef] [PubMed]

120. Lam, C.S.P.; Doehner, W.; Comin-Colet, J.; Lam, C.S. Iron deficiency in chronic heart failure: Case-based practical guidance. ESC Heart Fail. 2018, 5, 764-771. [CrossRef] [PubMed]

121. Ponikowski, P.; Voors, A.A.; Anker, S.D.; Bueno, H.; Cleland, J.G.F.; Coats, A.J.S.; Falk, V.; González-Juanatey, J.R.; Harjola, V.-P.; Jankowska, E.A.; et al. 2016 ESC Guidelines for the diagnosis and treatment of acute and chronic heart failure. Eur. Heart J. 2016, 37, 2129-2200. [CrossRef] [PubMed] 
122. Anker, S.D.; Colet, J.C.; Filippatos, G.; Willenheimer, R.; Dickstein, K.; Drexler, H.; Lüscher, T.F.; Bart, B.; Banasiak, W.; Niegowska, J.; et al. Ferric Carboxymaltose in Patients with Heart Failure and Iron Deficiency. N. Engl. J. Med. 2009, 361, 2436-2448. [CrossRef] [PubMed]

123. Ponikowski, P.; Van Veldhuisen, D.J.; Comin-Colet, J.; Ertl, G.; Komajda, M.; Mareev, V.; McDonagh, T.; Parkhomenko, A.; Tavazzi, L.; Levesque, V.; et al. Beneficial effects of long-term intravenous iron therapy with ferric carboxymaltose in patients with symptomatic heart failure and iron deficiency. Eur. Heart J. 2015, 36, 657-668. [CrossRef] [PubMed]

124. Lewis, G.D.; Malhotra, R.; Hernandez, A.F.; McNulty, S.E.; Smith, A.; Felker, G.M.; Tang, W.H.W.; LaRue, S.J.; Redfield, M.M.; Semigran, M.J.; et al. Effect of oral iron repletion on exercise capacity in patients with heart failure with reduced ejection fraction and iron deficiency the IRONOUT HF randomized clinical trial. JAMA 2017, 317, 1958-1966. [CrossRef] [PubMed]

125. Beck-Da-Silva, L.; Piardi, D.; Söder, S.; Rohde, L.E.; Pereira-Barretto, A.C.; De Albuquerque, D.; Bocchi, E.; Vilas-Boas, F.; Moura, L.Z.; Montera, M.W.; et al. IRON-HF study: A randomized trial to assess the effects of iron in heart failure patients with anemia. Int. J. Cardiol. 2013, 168, 3439-3442. [CrossRef] [PubMed]

126. Bekfani, T.; Pellicori, P.; Morris, D.; Ebner, N.; Valentova, M.; Sandek, A.; Doehner, W.; Cleland, J.G.; Lainscak, M.; Schulze, P.C.; et al. Iron deficiency in patients with heart failure with preserved ejection fraction and its association with reduced exercise capacity, muscle strength and quality of life. Clin. Res. Cardiol. 2019, 108, 203-211. [CrossRef] [PubMed]

127. Paterek, A.; Kepska, M.; Sochanowicz, B.; Chajduk, E.; Kołodziejczyk, J.; Polkowska-Motrenko, H.; Kruszewski, M.; Leszek, P.; Mackiewicz, U.; Mączewski, M. Beneficial effects of intravenous iron therapy in a rat model of heart failure with preserved systemic iron status but depleted intracellular cardiac stores. Sci. Rep. 2018, 8, 15758. Available online: http://www.nature.com/articles/s41598-018-33277-2 (accessed on 4 November 2018). [CrossRef] [PubMed]

(C) 2019 by the authors. Licensee MDPI, Basel, Switzerland. This article is an open access article distributed under the terms and conditions of the Creative Commons Attribution (CC BY) license (http://creativecommons.org/licenses/by/4.0/). 